\title{
Study of Acid DNase in Cow Snout Epidermis by Micro Slab Electrophoresis Using Acidic and Basic Gel Sheet
}

\author{
KEN YAEGAKI, RYOHEI OGURA, TOSHIHIRO HIDAKA, KUMI NAKAO, \\ HIROSHI UETA AND KEIJI MATUI \\ Department of Medical Biochemistry, Kurume University School of Medicine, \\ Kurume, 830 Japan
}

Received for publication December 1, 1987

\begin{abstract}
Summary: Electrophoretic profiles of acid DNase in cow snout epidermis were studied electrophoretically in relation to the depth of epidermis. Isoelectrophoretic point of acid DNase protein was found to be 4.9 and 8.4. To examine the electrophoretic properties of acidic and basic enzyme proteins, acid DNase was analyzed by micro slab electrophoresis, using $5 \%(\mathrm{pH} 4.3)$ and $10 \%(\mathrm{pH} 8.8)$ acrylamide gel sheet, respectively. Acid DNase was detected throughout all three successive layers of epidermis. In the case of acid DNase (basic protein) analysis carried out on the $\mathrm{pH} 4.3$ gel sheet, the additional minor component was found beside major band, in the upper layer of epidermis.
\end{abstract}

Key words: acid DNase - epidermis - slab electrophoresis - isoelectric point - basic protein

\section{Introduction}

It is known that a disappearance of nuclei from the border of the stratum corneum is one of the most characteristic features of the normal keratinization process in the epidermis (Santoianni et al. 1961). Nucleolytic enzymes concerned with DNA degradation are of great significance in the overall biological process of the epidermis. In' earlier studies (Mier et al. 1976; Ogura et al. 1978), the activities of the enzymes participating in the degradation of DNA were determined in cow snout epidermis, and their distribution was discussed in relation to the depth of epidermis. Förester et al. (1975) and Ogura et al. (1983) discussed electrophoretic properties of DNase in the epidermis by disc electrophoresis of polyacrylamide gel containing highly polymerized DNA.

To separate enzyme proteins with high sensitivity, micro slab electrophoresis with vertical sheet of polyacrylamide gel was applied (Been et al. 1972). Prior to slab electrophoresis, the isoelectric point of enzyme protein (DNase) was determined by micro U-shape isoelectric focussing technique. The electrophoretic slab-gel sheet was selected on the basis of the analysis of isoelectric point. To improve a separation of basic and acidic enzyme proteins, the $\mathrm{pH} 4.3$ and 8.8 polyacrylamide slab-gel sheets were prepared using a modification of procedure by Reisfeld et al. (1962). The successive horizontal slices of cow snout epidermis were examined to establish the electrophoretic properties of acid DNase in the epidermis in relation to the depth of epidermis.

\section{Materials and Methods}

Cow snouts were obtained from the slaughter house. The snouts were packed 
in an ice-cold container and brought back to the laboratory within 1 hour after death. The skin was excised and the subcutaneous tissue removed. The skin was cut into $3-4 \mathrm{~cm}$ square pieces, which were then sliced into serial horizontal sections with a cryostat-microtome. The slices obtained from the snout epidermis were separated into three successive layers: upper, middle and lower layer. The individual layers (approximately $0.5 \mathrm{~g}$ each) were homogenized in 7 volumes of $0.25 \mathrm{M}$ sucrose with a glass homogenizer. The homogenate was centrifuged at $600 \times \mathrm{g}$ for $10 \mathrm{~min}$. The resulting supernatant was used for enzyme assay.

\section{Micro Isoelectric Focussing}

A micro electrophoretic U-shape glass tube $(5 \times 340 \mathrm{~mm})$ was used for isoelectric $\mathrm{pH}$ (Ip) determination with ampholine $(\mathrm{pH}$ 3.5-10) containing sucrose gradient as described by Weller et al. (1968).

The isoelectric focussing was performed at $1.5 \mathrm{~mA}$ at $4^{\circ} \mathrm{C}$ for 15 hours. After electrophoresis, the solution was pushed out gently from the anode side by using peristaltic pump with sucrose solution. The effluent was divided into $0.16 \mathrm{ml}$ fractions. The fractions obtained were used immediately to determine the DNase activity and $\mathrm{pH}$ value.

\section{Assay of DNase Activity (acid DNase)}

DNase activity was determined by measuring spectrophotometrically the release of low molecular products from highly polymerized DNA, as described by Tabachnick (1964). For the assay of DNase activity, the reaction mixture contained $25 \mu \mathrm{l}$ of $0.2 \%$ salmon DNA-10 mM NaCl solution, $200 \mu \mathrm{l}$ of $0.1 \mathrm{M}$ acetate buffer ( $\mathrm{pH} \mathrm{5.0)}$ with $5 \mathrm{mM}$ EDTA, and $25 \mu \mathrm{l}$ of enzyme solution to be assayed. After $30 \mathrm{~min}$ incubation at $37^{\circ} \mathrm{C}$ in Eppendorf micro test-tube, $50 \mu \mathrm{l}$ of $15 \%$ perchloric acid was added to stop the reaction, chilled in an ice-cold water bath for $20 \mathrm{~min}$, and centrifuged at $12,000 \times \mathrm{g}$ for $5 \mathrm{~min}$. The optical density (OD) of the supernatant was determined at $260 \mathrm{~nm}$ by Beckman spectrophotometer ACTA CIII. A DNA blank and a sample blank were incubated simultaneously with each reaction tube and their values subtracted from the reading of each mixture. The enzyme activity (acid DNase activity) was expressed as OD $260 \mathrm{~nm}$ at above conditions.

\section{Micro Slab Electrophoresis}

The vertical micro-system for electrophoresis used here was designed by Yaegaki et al. (1982) with a modification described by Been et al. (1972). The apparatus consisted of an upper $(40 \times 45 \times$ $30 \mathrm{~mm}$ in height) and lower buffer chamber $(30 \times 80 \times 75 \mathrm{~mm}$ in height $)$. The gel sheet was $33 \times 55 \mathrm{~mm}$ in size. For the separation of basic and acidic protein, $5 \%(\mathrm{pH} \mathrm{4.3)}$ and $10 \%(\mathrm{pH} 8.8)$ acrylamide gel sheet, respectively, were used. A $100 \mu$ l of sample to be analyzed was loaded on the gel sheet. Egg lysozyme and bromphenol blue were used as markers for analysis of basic and acidic protein, respectively. The electrophoretic run with $15 \%$ acrylamide gel sheet ( $\mathrm{pH} 4.3$ ) was carried out at $4^{\circ} \mathrm{C}$ in $\beta$-alanine acetic acid buffer $(\mathrm{pH} \mathrm{4.5)}$ at $30 \mathrm{~mA}$ for $55 \mathrm{~min}$ with anode at the upper buffer chamber. The electrophoretic run with $10 \%$ acrylamide gel sheet ( $\mathrm{pH} \mathrm{8.8)}$ was carried out at $4^{\circ} \mathrm{C}$ in Tris glycin buffer (pH 8.4) at $20 \mathrm{~mA}$ for $40 \mathrm{~min}$ with cathode at the upper buffer chamber.

After electrophoresis, the removed acrylamide gel sheet was preincubated for $1 \mathrm{~h}$ at $4^{\circ} \mathrm{C}$ in acetate buffer ( $\mathrm{pH} \mathrm{5.0)}$ with $5 \mathrm{mM}$ EDTA. The gel sheet was placed upon $0.15 \%$ agarose sheet containing $0.06 \%$ DNA, using a modification of the procedure described by Kim et al. (1982). During incubation with overlapped sheets for $4 \mathrm{hrs}$ at $37^{\circ} \mathrm{C}$, DNA in agarose gel was degradated at the location corresponding to the electrophoretic mobility of DNase in the electrophoretic acrylamide sheet. Any remaining high-molecular DNA in 
agarose gel sheet was stained with $0.15 \%$ gallocyanin-5\% chromalaune. After destaining the excess stain with a running tap-water for over night, the position of DNase was identified as the discontinuity in the substrate background of gallocyaninchromalaune (Förester et al. 1975). The stained gel sheet was scanned with an Ozumor densitometer model OZ-802, Asaka, Japan, using red filter.

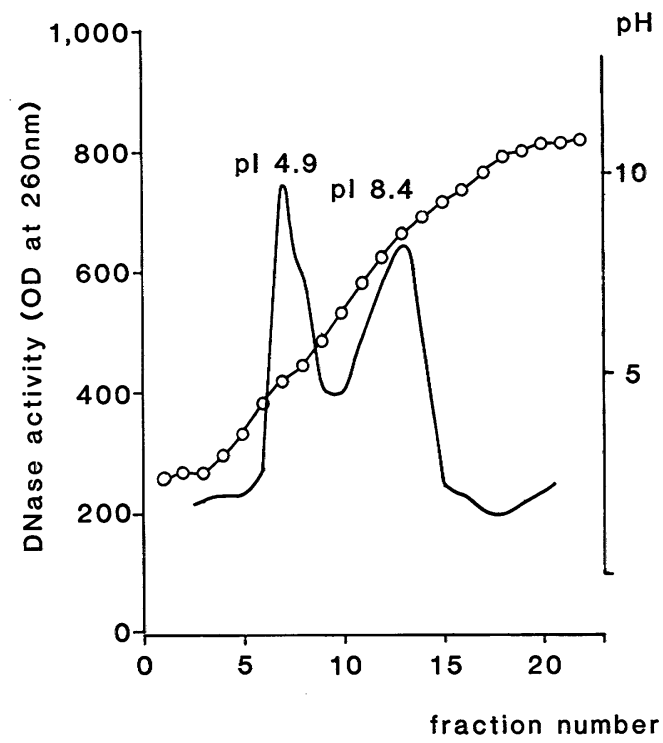

Fig. 1. Isoelectric focussing of acid DNase in cow snout epidermis. A micro electrophoretic U-shape glass tube $(5 \times 340 \mathrm{~mm})$ was prepared with ampholine ( $\mathrm{pH} 3.5-10.0)$ containing sucrose gradient. Abscissa indicates the fraction number of effluent $(0.16 \mathrm{ml}$ each) from the micro $U$-shape glass tube after electrophoresis.

\section{Results}

\section{Isoelectrophoretic Point}

As shown in Fig. 1, the isoelectrophoretic point of acid DNase was found to be 4.9 and 8.4 .

\section{Slab Electrophoresis}

In the DNA-containing agarose sheet overlapped with electrophoretic slab gel, the location of acid DNase was identified as clear in the dark blue-stained background. The electrophoretic pattern of the staining sheet was shown with transmission peak corresponding to DNase activity as shown in the densitometry tracings of DNA staining gel (Fig. 2 and 3 ). The acid DNase obtained in each of the three different layers exhibited a distinct major band in both $\mathrm{pH} 4.3$ and 8.8 gel sheets. In addition, minor peaks appeared in $\mathrm{pH} 4.3$ gel sheet, in particular in the sample from the upper layer.

To confirm the migration pattern of protein obtained with the slab electrophoresis, acrylamide gel sheet was stained with amidoblack. Several peaks appeared in the densitogram obtained from the $\mathrm{pH}$ 4.3 and 8.8 gel sheets (Fig. 4 and 5). As a marker, egg lysozyme or bromphenol blue (BPB) was mixed with sample to be assayed. These markers (arrow in the Fig. 4 and 5) migrated faster than the proteins. These results show that basic and acidic proteins migrate electrophoretically and can be separated satisfactorily by means of slab electrophoresis. The electrophoretic distance of DNase does not correspond with the electrophoretic mobility of the major parts of epidermal protein. 


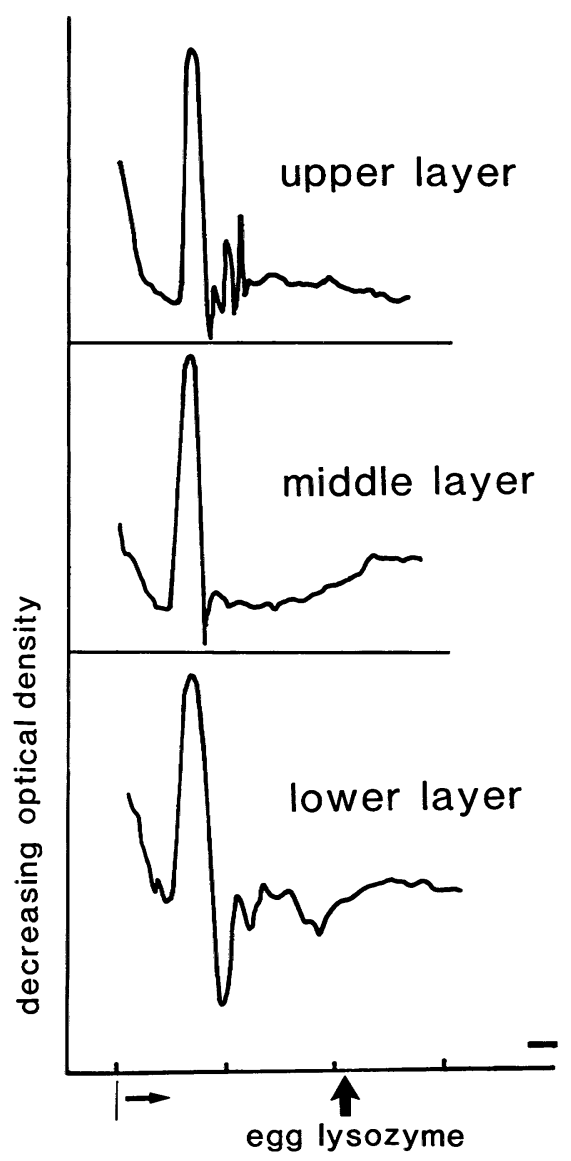

Fig. 2. Densitometry tracing of DNAcontaining $0.15 \%$ agarose gel sheet after overlapped with slab electrophoretic 15\% acrylamide gel sheet ( $\mathrm{pH} 4.3)$. The migration distance of the marker (egg lysozyme) is indicated with the arrow. The peak height in densitogram is in relation to DNase activity.

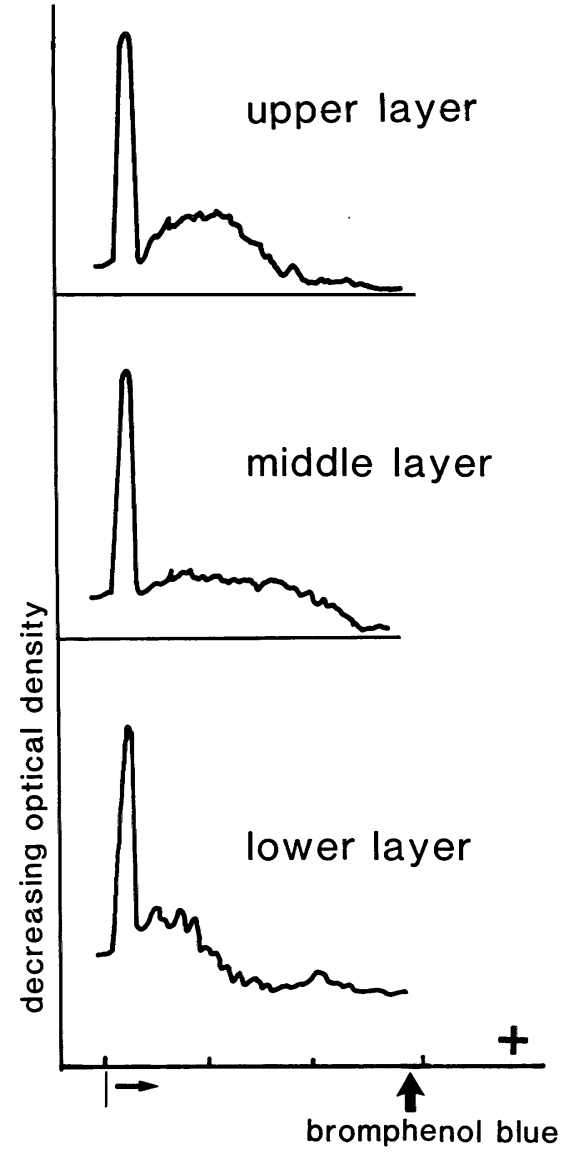

Fig. 3. Densitometry tracing of DNAcontaining $0.15 \%$ agarose gel sheet after overlapped with slab electrophoretic $10 \%$ acrylamide gel sheet ( $\mathrm{pH} 8.8$ ). The migration distance of the marker (bromphenol blue) is indicated with the arrow. The peak height in densitogram is in relation to DNase activity. 


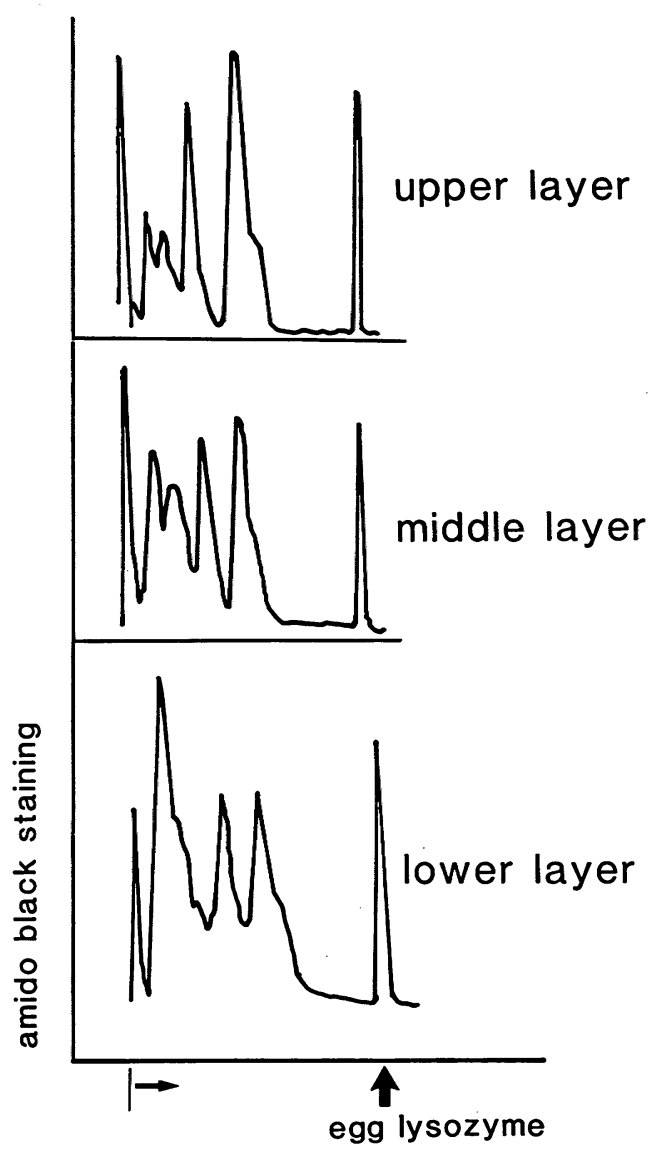

Fig. 4. Migration pattern of protein with slab electrophoresis, $15 \%$ acrylamide gel sheet ( $\mathrm{pH} \mathrm{4.3)}$ was stained with amidoblack. The migration distance of the marker (egg lysozyme) is indicated with the arrow.

\section{Discussion}

The electrophoretic properties of proteins have become a matter of discussion, as it was shown that the basic protein does not migrate readily in commonly used systems of electrophoresis. In the present paper, the slab electrophoresis was carried out with respect to cow snout epidermis, to distinguish between basic and acidic protein. In the case of analysis of basic protein, the $\mathrm{pH} 4.3$ electrophoretic gel

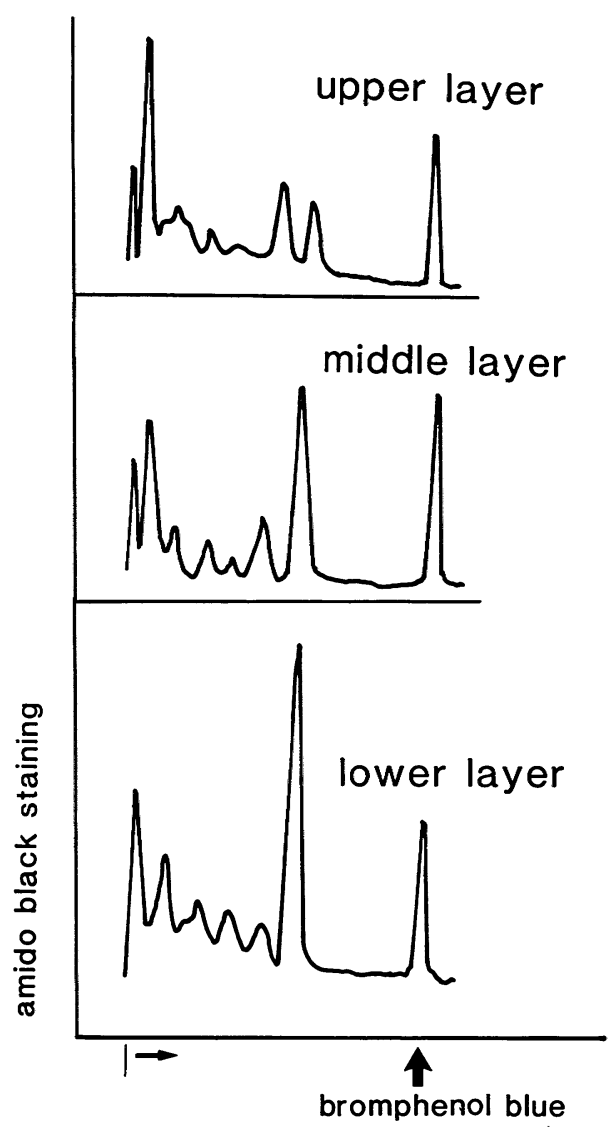

Fig. 5. Migration pattern of protein with slab electrophoresis; $10 \%$ acrylamide gel sheet ( $\mathrm{pH}$ 8.8) was stained with amidoblack. The migration distance of the marker (bromphenol blue) is indicated with the arrow.

sheet was prepared using a modification of the procedure described by Reisfeld et al. (1962). This technique led to an excellent resolution of mixtures of basic proteins. Yaegaki (1982) has also applied this procedure to analyze the acid DNase of rat submandibular gland and to demonstrate that both acid and basic protein were heterogeneous.

In the previous study (Ogura et al. 1983), DNase of cow snout epidermis was analyzed using commonly used disk elec- 
trophoresis ( $\mathrm{pH} 8.8$ only). In that study, acid DNase exhibited only a single distinct band throughout all three layers of epidermis. The present analysis of isoelectric point demonstrated that acid DNase protein is heterogeneous ( $\mathrm{p} 1: 4.9$ and 8.4). In the case of the slab electrophoresis with the $\mathrm{pH} 4.3$ gel sheet, it was shown at present that acid DNase prepared from the upper layer of epidermis shows minor additional bands, beside the major band.

It has been reported that a negligible amount of DNA is present in the normal stratum corneum (Santoianni et al. 1961). The DNA molecule is degraded completely at the border of stratum corneum; hydrolytic enzymes are involved in this catabolism of nucleic acid of the epidermis. The distribution of hydrolytic enzyme activity was reported in relation to the depth of cow snout epidermis by Mier et al. (1976) and Ogura et al. (1978). The majority of acid hydrolases showed a clear peak in the basal and lower spinous cell layers, while acid phosphatase was found mainly in keratinizing zone (Mier et al. 1976). Enzymes participating in the degradation of DNA were found to show the maximal activity in the upper layer (Ogura et al. 1978). Acid DNase activity in cow snout epidermis was $10.5 \pm 1.2,7.2 \pm 1.0,5.3 \pm 1.2$ unit per $\mathrm{mg}$ protein respectively, with respect to the depth of epidermis. The highest activity was present in the upper layer of epidermis. In fact, the DNA content was found to decrease progressively with the differentiation of epidermal cells (Ogura et al. 1978). The DNA content per mg protein fell down to a low level in the upper layer, amounting at most to only about one third of DNA content in the lower layer (Ogura et al. 1978). In the present paper, acid DNase was present in all three successive layers of epidermis. In the case of basic protein, it is interesting to note that the additional minor peaks of acid DNase appear in the upper layer in addition to the major peak. The physiological significance of basic protein which appears in the upper layer is unknown.

\section{References}

BEEN, A.C. and RASCH, E.M. (1972). A vertical microsystem for discontinuous electrophoresis of insect tissue proteins using thin sheets of polyacrylamide gel. J. Histochem. and Cytochem. 20, 368-384.

Förester, F. J., Leonhardi, G., Zöllner, E. J. and $Z_{\mathrm{AHN}}, \mathrm{R} . \mathrm{K}$. (1975). Separation of deoxyribonucleases of normal human stratum corneum and psoriatic scales by microdisc-electrophoresis. Arch. Derm. Res. 253, 213-218.

Kim, H.S. and LiaO, T. (1982). Isoelectric focusing of multiple forms of DNase in thin layers of polyacrylamide gel and detection of enzymatic activity with a zymogram method following separation. Anal. Biochem. 119, 96101.

Mier, P.D., Cotton, D.W.K., Von Den hurk, J.M. A. and JonckheERvanneste, M. M. H. (1976). Lysosomal hydrodases of the epidermis. Brit. J. Dermat. 94, 535-538.

Ogura, R., Koga,H., Kinoshita, M. and Takashima, Y. (1978). Distribution of enzymes of nucleic acid metabolism in cow snout epidermis. Brit. J. Dermat. 98, 362-410.

Ogura, R., Ueda, T., Kumano, S., Sakata, T., ZöllnER, E. J. and ZAHN, R.K. (1983). Microdisc-electrophoretic study of deoxyribonucleases in cow snout epidermis. Arch. Dermat. Res. 275, 213-217.

Reisfeld, R. A., Lewis, U. J. and Williams, D.E. (1962). Disc-electrophoresis of basic proteins and peptides on polyacrylamide gels. Nature. London, 195, 281-283.

Santolannni, P. and Rothman, S. (1961). Nucleic acid splitting enzymes in human epidermis and their possible role in keratinization. J. Invest. Dermat. 37, 489-495.

TABACHNick, J. (1964). Studies of the biochemistry of epidermis (II). J. Invest. Dermat. 42, 471478.

Weller, D. L. Heaney, A. and Sjogren, R.E. (1968). A simple apparatus and procedure for electrofocussing experiments. Biochem. Biophys. Acta. 168, 576-579.

YAEGAKI, K. (1982). Subcellular distribution of DNase II of rat submandibular gland and in sialoadenitis. J. Kurume Med. Assoc. 45, 975992. (in Japanese). 